\title{
Endothelial Progenitor Cells are Increased in Patients with Advanced Pancreatic Cancer Treated with Gemcitabine and Intravenous Omega 3 Compared with Controls
}

John Isherwood ( $\sim$ John.d.isherwood@outlook.com )

University of Leicester

\section{Ali Arshad}

University Hospital Southampton NHS Foundation Trust

\section{Wen Chung}

University Hospitals of Leicester NHS Trust

\section{Franscois Runau}

University Hospitals of Leicester NHS Trust

Jill Cooke

University Hospitals of Leicester NHS Trust

\section{Cristina Pollard}

University Hospitals of Leicester NHS Trust

Lynne Howells

University of Leicester

Jenny Fishwick

University of Leicester

John Thompson

University of Leicester

\section{Matthew Metcalfe}

University Hospitals of Leicester NHS Trust

William Steward

University of Leicester

\section{Ashley Dennison}

University Hospitals of Leicester NHS Trust

\section{Research article}

Keywords: Pancreatic cancer, Endothelial progenitor cells, Omega-3 fatty acids

Posted Date: July 9th, 2020

DOI: https://doi.org/10.21203/rs.3.rs-36878/v1

License: (c) (i) This work is licensed under a Creative Commons Attribution 4.0 International License. Read Full License 


\section{Abstract}

Introduction Pancreatic adenocarcinoma (PAC) is a devastating disease. Endothelial progenitor cells (EPCs) are important mediators in PAC. Omega 3 fatty acids ( $\omega$-3FAs) have been shown to have anti-inflammatory properties.

Methods This was a single centre study investigating intravenous $\omega$-3FAs and gemcitabine chemotherapy versus gemcitabine therapy alone in patients with APC. The primary outcome measure was the level of EPCs with the secondary outcome measure being the relationship between the EPC levels, progression free survival and overall survival.

Results Over the treatment period $\mathrm{CD} 45^{-}, \mathrm{CD} 31^{+}, \mathrm{CD} 133^{+} \mathrm{EPCs}$ and $\mathrm{CD} 45^{-}, \mathrm{CD} 31^{+}, \mathrm{CD} 34^{+}$EPCs significantly increased $(\mathrm{P}=0.042$ and $P=0.0001)$, whilst no change was observed in control EPCs $(P=0.705)$. There was a non-significant downward trend in control EPCs $(P=0.930,95 \%)$. There was a significant difference between the trial and control patients over time on logistic regression analysis $(P=0.0001)$. There was a significant increase in $C D 45^{-}, C D 34^{+}, C D 31^{+}$and $C D 133^{+}$EPCs trial EPCs over treatment $(P=0.007)$. There was no significant increase seen in control EPCs $(P=0.358,95 \%)$. There was a significant difference between the trial and control patients over treatment on logistic regression analysis $(P=0.0001)$. There was a significant correlation in the trial patients between progression free survival benefit and an increase in EPCs.

Conclusion Intravenous $\omega$-3FAs with gemcitabine chemotherapy in APC results in a significantly increased level of EPCs. There appears to be a survival benefit in patients with an increase in EPCs which may be the result of a reduction in pro-inflammatory mediators.

\section{Introduction}

Pancreatic adenocarcinoma (PAC) is a devastating diagnosis with the majority of patients presenting with advanced pancreatic cancer (APC). The incidence of the disease approximates to the mortality, with around 7,500 to 8,000 new cases and deaths each year in the UK, making it the 5th most common cause of cancer death(1). For those diagnosed with unresectable cancer the life expectancy is approximately 8 months $(2,3)$. Pancreatic adenocarcinoma almost ubiquitously metastasises, predominantly to the liver, lungs and abdomen and invades important surrounding anatomical structures at an early stage(4). Of all presenting pancreatic adenocarcinomas cancers, approximately $20 \%$ will be operable with curative intent with the remaining majority receiving palliative treatment(5).

\section{EPCs}

Vasculogenesis is the process by which blood vessels are formed de novo and angiogenesis is the expansion and remodelling of the existing blood vessel network(6). The process of angiogenesis is regulated by multiple pro- and anti- angiogenic mediators and growth factors. The imbalance of these anti- and pro- angiogenic factors activates an "angiogenic switch"(7), and involves a myriad participating cells. Tumours can form vessels by "hijacking" neighbouring pre-existing vessels(8) but there is increasing evidence that vasculogenesis, through which bone marrow derived hematopoietic stem cells and endothelial progenitors home into to tumour sites(9), plays an important role. Cancer progression requires new vessel formation to deliver oxygen, nutrients and growth factors and tumours are therefore key promoters of vasculogenesis and angiogenesis. Tumours such as PAC have a hypoxic environment and circulating endothelial progenitor cells (EPCs) are mobilised in response to the tissue hypoxia which ensures the promotion of angiogenesis. A number of studies have shown that EPCs have the ability to form colonies in vitro, highlighting their role in angiogenesis(10), the maintenance of existing vascular structures(11), and tumour vasculogenesis(12) and as a consequence, changes in these cell numbers could potentially be advantageous in a clinical setting.

\section{Omega 3 Fatty Acids}


$\omega$-3FAs have been shown to have anti-inflammatory properties and there is abundant research demonstrating the benefit of $\omega$-3FAs in PAC, from cell culture and animal models through to human clinical trials. In vitro $\omega$-3FAs have been shown to inhibit the growth of human pancreatic cancer, augment the effect of gemcitabine, induce apoptosis, and inhibit the proliferation and invasion of $\operatorname{PAC}(13,14)$.

The incorporation of $\omega$-3FAs into the cell membrane alters its composition and they play an important role in membrane protein function and intracellular fatty acid receptors(15), maintaining membrane fluidity(16), influencing lipid raft formation(17) and crucially are metabolised to secondary messengers and metabolites(18) (Fig. 1). Intravenous w-3FAs may also change the EPC profile seen in PAC conferring clinical benefit and indicating a potential area for future therapeutic strategies.

Figure 1. Eicosanoids derived from $\omega-3$ FAs (EPA and DHA) and $\omega-6$ FAs (AA). They are metabolised by cyclooxygenase and lipoxygenase. The anti-inflammatory eicosanoids produced by $\omega$-3FAs include the 3 series prostaglandins and thromboxanes and the 5 series leukotrienes. The pro inflammatory eicosanoids produced by $\omega-6 F A s$ include the 2 series prostaglandins and thromboxanes and the 4 series leukotrienes. Increasing the amount of $\omega$-3FAs improves the $\omega-3$ FAs: $\omega$-6FAs ratio and reduces the amount of $\omega-6 F A s$, particularly AA, present in the cell membrane and therefore the amount available for downstream pro inflammatory eicosanoid production. All these secondary mediators have either a general suppressive or enhancing effect on growth factors and cells in the inflammatory microenvironment.

\section{Methods}

Twenty-seven patients were recruited, eighteen in a non-randomised manner as part of a phase two, single arm, and singlecentre study of gemcitabine plus intravenous $\omega-3 F A s$ in patients with chemotherapy-naïve advanced pancreatic cancer. This trial was registered with cinicaltrials.gov: NCT01019382. Nine subsequent control patients who had received standard gemcitabine monotherapy were also recruited in a non-randomised manner. The local Ethics Committee and the Medicines and Healthcare Products Regulatory Agency (MHRA) approved both studies. All patients had a histological diagnosis of APC. All patients were discussed at the local multi-disciplinary team meeting and were assessed by an oncologist and considered suitable to receive gemcitabine chemotherapy. All patients were assessed against trial protocol inclusion/exclusion criteria.

\section{Treatment protocol}

Patients received a standard dose of gemcitabine $\left(1000 \mathrm{mg} / \mathrm{m}^{2}\right)$ administered as a thirty minute infusion once weekly for three weeks, followed by a one week break from treatment up to a maximum of six months. Immediately following each administration of gemcitabine patients received up to $500 \mathrm{~mL}$ of a lipid emulsion intravenously (Lipidem, BBraun) containing $10 \mathrm{~g} \omega-3$ fatty acids (0.5-1 g ALA and 4.3-8.6 g EPA/DHA) over four hours and all patients received at least $250 \mathrm{~mL}$ of Lipidem $^{\mathrm{T}}$. Control patients received gemcitabine treatment alone at a standard dose prescribed weekly by an oncologist with dose adjustments as per standard clinical practice. Patients were included in the study until progression of disease, death, serious adverse events necessitating withdrawal or patients withdrawing from treatment. A CT scan was performed at baseline, at any stage if disease progression was suspected, or every eight weeks. Patients continued in the trial as long as their tumour did not demonstrate progression as defined by the modified Response Evaluation Criteria in Solid Tumours (RECIST) criteria which was assessed by an independent radiologist. Blood samples were obtained at each treatment time point and kept on ice prior awaiting sample processing which occurred immediately following collection.

\section{PMBC separation, storage and preparation}

Blood samples consisting of $19.6 \mathrm{~mL}$ of whole blood were collected in $4 \times 4.9 \mathrm{~mL}$ Ethylenediaminetetraacetic acid (EDTA) bottles from each patient at each treatment point following the completion of the treatment. Peripheral blood mononuclear cells (PBMCs) were isolated using standard protocols with a density gradient separation solution (Ficoll-Paque ${ }^{\text {TM }}$ PREMIUM 1.084) and stored in an $-80^{\circ} \mathrm{C}$ freezer. Samples were snap-thawed at $37^{\circ} \mathrm{C}$ in a temperature controlled water bath. The samples were 
washed and isolated and the cell number and percentage of viable cells was then determined prior to antibody staining using the cell counting protocol.

\section{Sample staining and Flow cytometry analysis}

PBMCs were analysed for EPCs. EPCs with three antibody phenotypes were analysed: $1 . \mathrm{CD}_{4} 5^{-}, \mathrm{CD} 31^{+}$and $\mathrm{CD} 133^{+}, 2 . \mathrm{CD}^{4} 5^{-}$, $\mathrm{CD}_{1} 1^{+}$and $\mathrm{CD} 34^{+}$and $3 . \mathrm{CD} 45^{-}, \mathrm{CD} 31^{+}, \mathrm{CD} 133^{+}$and $\mathrm{CD} 34^{+}$. Antibodies utilised to identify EPCs included CD31 FITC Mouse Anti-Human. BD Pharmingen ${ }^{8}$, CD 45 Pacific Blue Mouse Anti-Human. BD Pharmingen ${ }^{\circledR}$ (Berkshire, UK), CD34 PE Mouse AntiHuman. BD Pharmingen ${ }^{\circledR}$ and CD133 APC. Miltenyi Biotec ${ }^{\circledR}$ (Surrey, UK). Samples were analysed for unstained cells, each individual antibody and a combination stain. Cells were processed using standard protocols. Samples were analysed with the FACS Aria II flow cytometer (Becton Dickinson, BD Biocsiences, San Jose, USA). Each sample was analysed for the unstained cells, each individual antibody evaluation and the overall combination analysis (Fig. 2).

Figure 2. FACS schematic scatter plots of EPCs with a quadruple stain for $\mathrm{CD} 45^{-}, \mathrm{CD} 31^{+}, \mathrm{CD} 133^{+}$and $\mathrm{CD} 34^{+}$antibodies. The top left plot shows side scatter (SSC) versus forward scatter (FSC). A mean of 374,796 cells in the target population (P1) were analysed over the one hundred and thirty-four samples investigated. Three populations of EPCs were analysed. EPCs with a $\mathrm{CD}_{4}{ }^{-}, \mathrm{CD} 1^{+}, \mathrm{CD}_{133^{+}}$and $\mathrm{CD} 34^{+}$phenotype are seen in Q2.2 $\left(\mathrm{CD} 133^{+}(\mathrm{APC})\right.$ and CD34 $\left.{ }^{+}(\mathrm{PE})\right)$, gated off P6 (CD31 ${ }^{+}(\mathrm{FITC}) \&$ $\mathrm{CD}^{-} 5^{-}$(R/B220 pacific blue). EPCs with a CD45- ${ }^{-}$CD31 ${ }^{+}$and CD34 ${ }^{+}$phenotype are seen in Q2.1 $\left(\mathrm{CD} 34^{+}(\mathrm{PE})\right.$ and $\left.\mathrm{CD} 31^{+}(\mathrm{FITC})\right)$, gated off P3 (CD45- (R/B220 pacific blue). EPCs with a CD45- CD31 ${ }^{+}$and CD133 phenotype are seen in Q2 (CD31+ (FITC) and CD133+ (APC)), gated P3 (CD45- (R/B220 pacific blue).

\section{Statistical analysis}

Overall and progression free survival data was analysed with Kaplan-Meir curves and a log-rank (Mantel-Cox) test. Clinical outcomes were correlated with changes in mediators and survival curves analysed with a log-rank (Mantel-Cox) test. Changes in cells over the trial in both trial and control patients and between groups were analysed with logistic regression analysis using STATA software. A mixed effects logistic regression model was utilised that allowed for random variation and missed time points. These statistical models were chosen as the clinical trial data varied in length depending on individual treatment, in addition to missing time points resulting from the unavoidable factors, both patient and investigator related, in a clinical trial.

\section{EPC measurement}

EPCs are rare cells and make up between $0.01 \%$ and $0.001 \%$ of mononuclear cells in normal peripheral blood(19). The number of circulating $\mathrm{CD}_{3} 4^{+}$cells is around $50-100$ per million white blood cells $(0.005-0.001 \%)$, equal to about $350-700$ cells per $\mathrm{mL}(20)$, and there are some report that suggest co-expression of CD133 increases the specificity for EPCs as it is not expressed on mature endothelial cells $(20,21)$. This co-expression of CD34 and CD133 cells in peripheral blood is even lower and makes quantification significantly more difficult. In order to compensate for this, most researcher groups acquire large amounts of cells or events. Strict criteria for the separation of cells, titrating of antibodies and the use of high-end flow cytometry machines and methods are essential. No universal agreement regarding phenotypic identification and lack of methodological consensus compounds the variability in the published literature. As a consequence there is wide variability in reported phenotypic subtypes that include a variety of markers (Table 1). There are also inconsistencies in the reporting of results, with some studies reporting EPCs for a sample volume and EPCs for a defined number of mononuclear cells(22). EPCs in this study were separated, processed, analysed and identified according to literature standards. EPCs are reported as a percentage of the parent population and three EPC phenotypes were examined. 
Table 1

Antibody phenotypes and characteristics from select studies.

\begin{tabular}{|c|c|c|c|c|c|c|c|c|}
\hline \multirow[t]{2}{*}{ Study } & \multirow[t]{2}{*}{ Pathology } & \multirow[t]{2}{*}{ Subjects } & \multicolumn{6}{|c|}{ Antibody } \\
\hline & & & CD45- & CD31+ & CD133+ & CD34+ & CD146- & VEGFR2 \\
\hline Vizio et al (2010) ${ }^{8}$ & PAC & Human & $\mathrm{Y}$ & Y & $\mathrm{Y}$ & Y & & \\
\hline $\begin{array}{l}\text { Sakamori et al } \\
(2012)^{54}\end{array}$ & NSCLC & Human & $\mathrm{Y}$ & Y & $\mathrm{Y}$ & Y & & \\
\hline Morita et al (2011) 55 & NSCLC & Human & $\mathrm{Y}$ & Y & Y & Y & & \\
\hline Steurer et al $(2008)^{56}$ & NSCLC & Human & $\mathrm{Y}$ & Y & $\mathrm{Y}$ & Y & & \\
\hline $\begin{array}{l}\text { Roodhard et al } \\
(2010)^{57}\end{array}$ & Various* & Human & $\mathrm{Y}$ & $\mathrm{Y}$ & $\mathrm{Y}$ & & & \\
\hline Li et al $(2011)^{58}$ & PAC & Mouse & & & Y & Y & $\mathrm{Y}$ & \\
\hline $\begin{array}{l}\text { Staringer et al } \\
(2011)^{59}\end{array}$ & PAC & Human & $\mathrm{Y}$ & Y & & & $\mathrm{Y}$ & \\
\hline Kuo et al (2012) & Breast & Human & $\mathrm{Y}$ & $\mathrm{Y}$ & $\mathrm{Y}$ & & $\mathrm{Y}$ & \\
\hline Lin et al $(2013)^{60}$ & Rectal cancer & Human & $\mathrm{Y}$ & $\mathrm{Y}$ & $\mathrm{Y}$ & & & Y \\
\hline Fuereder et al (2014) 61 & Prostate cancer & Human & Y & Y & Y & & Y & \\
\hline DuBois et al $(2012)^{62}$ & Osteosarcoma & Human & $\mathrm{Y}$ & Y & $\mathrm{Y}$ & & $\mathrm{Y}$ & \\
\hline Corsini et al (2012) ${ }^{63}$ & Glioma & Human & $\mathrm{Y}$ & & Y & Y & & \\
\hline Kim et al (2013) 64 & $\begin{array}{l}\text { Gynaecological } \\
\text { cancers }\end{array}$ & Human & $\mathrm{Y}$ & & $\mathrm{Y}$ & Y & & Y \\
\hline Bhatt et al (2011) 65 & Renal cell carcinoma & Human & $\mathrm{Y}$ & & $\mathrm{Y}$ & $\mathrm{Y}$ & $\mathrm{Y}$ & \\
\hline Ha et al $(2013)^{66}$ & Gastric cancer & Human & & & Y & Y & & \\
\hline Marlicz et al $(2016)^{67}$ & Colorectal cancer & Human & Y & & Y & Y & & Y \\
\hline $\begin{array}{l}\text { Starzynske et al } \\
(2013)^{40}\end{array}$ & PAC & Human & $\mathrm{Y}$ & Y & & Y & & Y \\
\hline Ko et al $(2010)^{42}$ & PAC & Human & Y & Y & & Y & & \\
\hline Steurer et al $(2008)^{56}$ & NSCLC & Human & $\mathrm{Y}$ & $\mathrm{Y}$ & & Y & & Y \\
\hline Shim et al $(2015)^{68}$ & Myocardial infarction & Human & Y & Y & & Y & $\mathrm{Y}$ & \\
\hline Mancuso et al (2011) & Breast cancer & Human & $\mathrm{Y}$ & $Y$ & & $Y$ & & \\
\hline
\end{tabular}

Table 1. Demographic characteristics of the study participants and the number of treatment time points and completed cycles per group. A treatment cycle included three treatment points (each week) and a rest week.

Table 1. Antibody phenotypes and characteristics from select studies. There is wide discrepancy in the antibody phenotypes used to identify EPCs. In PAC the antibody phenotype of CD45- CD $31^{+}, \mathrm{CD} 34^{+} \&$ CD $133^{+8}$ and $\mathrm{CD} 45^{-}, \mathrm{CD} 31^{+}$and $\mathrm{CD} 34^{+40,42}$. However the phenotype of $\mathrm{CD}^{2} 5^{-}, \mathrm{CD} 34^{+} \& \mathrm{CD} 133^{+}$has been investigated in various other cancers as shown above. NSCLC: Non-small cell lung cancer. VEGFR2: Vascular endothelial growth factor receptor 2. PAC: Pancreatic adenocarcinoma. Various*: Cancers studied include breast, colorectal, ovarian, oesophagus, prostate, head and neck, sarcoma, cervical and others not 
described. CD45: A hematopoietic marker also known as the Leukocyte Common Antigen which is present on all human leucocytes, including lymphocytes, monocytes, granulocytes, eosinophils and thymocytes. It is absent from erythrocytes, platelets or mature erythroid cells of bone marrow and non-haemopoietic tissues. CD31: An endothelial cell marker also known as PECAM-1 (Platelet And Endothelial Cell Adhesion Molecule 1), It is implicated in angiogenesis ${ }^{69}$, vascular wound healing and transendothelial migration of leukocytes in inflammatory processes. It is widely expressed on endothelial cells as well as platelets, monocytes and granulocytes. CD34: An endothelial cell marker also known as the hematopoietic progenitor cell antigen, it is expressed on hematopoietic progenitor cells, vascular endothelium and some tissue fibroblasts. CD133: An early hematopoietic stem cell marker, CD133 is expressed on circulating endothelial progenitor cells ${ }^{21,31}$. In the hematopoietic system, CD133 expression is restricted to a subset of CD34 bright stem and progenitor cells in human foetal liver, bone marrow, cord blood and peripheral blood ${ }^{70}$. CD146: Also known as melanoma cell adhesion molecule or MCAM it belongs to the immunoglobulin superfamily. It is expressed in epithelial cells, activated T cells, endothelial cells and multipotent mesenchymal stromal cells ${ }^{71}$. VEGFR-2: An endothelial marker.

\section{Results}

Patient demographics are shown in Table 2. A total of twenty-seven patients were recruited, eighteen trial and nine control patients. EPCs with three antibody phenotypes were analysed. There was a significant increase in $\mathrm{CD}_{4} 5^{-}, \mathrm{CD} 31^{+}$and $\mathrm{CD} 133^{+}$ EPCs over the treatment period $(P=0.042$, Fig. 3). There was no significant change in EPCs in the control group $(P=0.705,95 \%$ $\mathrm{Cl}=-0.023-0.034)$. Overall there was no significant difference between the trial and control patients over treatment on logistic regression analysis $(P=0.332)$. There was a significant increase in $\mathrm{CD}_{4} 5^{-}, \mathrm{CD} 31^{+}$and $\mathrm{CD} 34^{+} \mathrm{EPCs}$ over the treatment period $(\mathrm{P}$ $=0.0001$, Fig. 4). There was a non-significant downward trend in control EPCs seen $(P=0.930,95 \% \mathrm{Cl}=-0.029-0.027)$. Overall there was a significant difference between the trial and control patients over time on logistic regression analysis $(P=0.0001)$. In $\mathrm{CD} 45^{-}, \mathrm{CD} 34^{+}, \mathrm{CD} 31^{+}$and $\mathrm{CD} 133^{+} \mathrm{EPC}$ s there was a significant increase in trial EPCs over treatment $(P=0.007$, Fig. 5). There was no significant increase seen in control EPCs $(P=0.358,95 \% \mathrm{Cl}=-0.016-0.466)$. There was a significant difference between the trial and control patients over the treatment period on logistic regression analysis $(P=0.0001)$. 
Table 2

Patient demographics.

\begin{tabular}{|llll|}
\hline Demographics & & Trial patients N=18 & Control Patients N=9 \\
\hline Gender & Male & 10 & 7 \\
& Female & 8 & 2 \\
\hline Age & Median age (range) & $70(59-83)$ & $64(50-75)$ \\
& $>$ 70 years & 8 & 2 \\
\hline Ethnicity & White British & 10 & 8 \\
\hline Baseline Weight & Median weight in Kilograms (range) & $62.1(48.6-81)$ & $69.1(54.2-86)$ \\
\hline Stage & Stage 3 & 7 & 5 \\
\hline Sotal number of treatment time points (median) & 16 & 4 \\
\hline Number of patients completed 1 cycle (\%) & 11 & $38(3)$ \\
\hline Number of patients completed 2 cycles (\%) & $14(78 \%)$ & $5(63 \%)$ \\
\hline Number of patients completed 4 cycles (\%) & $11(61 \%)$ & $2(25 \%)$ \\
\hline Number of patients completed 6 cycles (\%) & $7(39 \%)$ & $1(12.5 \%)$ \\
\hline
\end{tabular}

Table 2. Antibody phenotypes and characteristics from select studies. There is wide discrepancy in the antibody phenotypes used to identify EPCs. In PAC the antibody phenotype of CD45, CD 31 ${ }^{+}, \mathrm{CD}_{3} 4^{+} \& \mathrm{CD} 133^{+}(8)$ and $\mathrm{CD} 45^{-}, \mathrm{CD} 31^{+}$and CD $34^{+}$ $(40,42)$. However the phenotype of $C D 45, C D 34^{+} \& C D 133^{+}$has been investigated in various other cancers as shown above. NSCLC: Non-small cell lung cancer. VEGFR2: Vascular endothelial growth factor receptor 2. PAC: Pancreatic adenocarcinoma. Various*: Cancers studied include breast, colorectal, ovarian, oesophagus, prostate, head and neck, sarcoma, cervical and others not described. CD45: A hematopoietic marker also known as the Leukocyte Common Antigen which is present on all human leucocytes, including lymphocytes, monocytes, granulocytes, eosinophils and thymocytes. It is absent from erythrocytes, platelets or mature erythroid cells of bone marrow and non-haemopoietic tissues. CD31: An endothelial cell marker also known as PECAM-1 (Platelet And Endothelial Cell Adhesion Molecule 1), It is implicated in angiogenesis (54), vascular wound healing and transendothelial migration of leukocytes in inflammatory processes. It is widely expressed on endothelial cells as well as platelets, monocytes and granulocytes. CD34: An endothelial cell marker also known as the hematopoietic progenitor cell antigen, it is expressed on hematopoietic progenitor cells, vascular endothelium and some tissue fibroblasts. CD133: An early hematopoietic stem cell marker, CD133 is expressed on circulating endothelial progenitor cells(21,31). In the hematopoietic system, CD133 expression is restricted to a subset of CD34 bright stem and progenitor cells in human foetal liver, bone marrow, cord blood and peripheral blood (55). CD146: Also known as melanoma cell adhesion molecule or MCAM it belongs to the immunoglobulin superfamily. It is expressed in epithelial cells, activated T cells, endothelial cells and multipotent mesenchymal stromal cells(56). VEGFR-2: An endothelial marker.

Demographic characteristics of the study participants and the number of treatment time points and completed cycles per group. A treatment cycle included three treatment points (each week) and a rest week.

Figure 3. Output graph showing regression lines for individual patients plotted against time in weeks following mixed effects logistic regression analysis. EPCs levels are shown on the $y$ axis and are a calculated as a percentage of the parent population ( $\log$ scale), time in weeks is shown on the $x$ axis. Each regression line represents a patient. One hundred and three time points in eighteen patients were analysed. There was a significant increase in EPCs over treatment $(P=0.042,95 \% \mathrm{Cl}=0.0008-0.046)$.

Page $7 / 20$ 
Figure 4. Output graph showing regression lines for individual patients plotted against time in weeks following mixed effects logistic regression analysis. EPCs levels are shown on the $y$ axis and are a calculated as a percentage of the parent population (log scale), time in weeks is shown on the $x$ axis. Each regression line represents a patient. One hundred and two time points in eighteen patients were analysed. There was a significant overall increasing trend in EPCs over time $(P=0.0001,95 \% \mathrm{Cl}=0.132-$ 0.385).

Figure 5. Output graph showing regression lines for individual patients plotted against time in weeks following mixed effects logistic regression analysis. EPCs levels are shown on the $y$ axis and are a calculated as a percentage of the parent population (log scale), time in weeks is shown on the $x$ axis. Each regression line represents a patient. Twenty-seven samples in nine patients were analysed. EPCs are calculated as a percentage of the parent population and plotted on a log scale. One hundred and three time points in eighteen patients were analysed. There is a significant increase in EPCs over time $(P=0.007,95 \% \mathrm{Cl}=$ $0.006-0.377)$.

\section{Survival analysis}

EPCs in both trial and control patients were divided into two groups (low and high change groups) around the median percentage change in EPCs between baseline and end point. Overall survival (OS) and progression free survival (PFS) of trial and control patients were compared in the low and high change groups. Patient T10 was excluded from this analysis as the patient became operable. Patients $\mathrm{C} 5, \mathrm{C} 7, \mathrm{C} 9, \mathrm{~T} 7, \mathrm{~T} 12$ and $\mathrm{T} 14$ were excluded from the analysis as they had no sample following a baseline measurement.

In $\mathrm{CD} 45^{-}, \mathrm{CD} 31^{+}$and $\mathrm{CD} 133^{+}$EPCs there was a significant PFS benefit in trial patients demonstrating a large change in EPCs versus control patients $(P=0.0023)$. There was also a significant $O S$ benefit seen in trial patients with a large change in EPCs compared with control patients $(P=0.019)$. In $C D 45^{-}, C D 31^{+}$and $C D 34$ EPCs there was no significant difference in PFS in patients. There was a minimal change in EPCs in trial versus control patients $(P=0.42)$. There was a significant PFS benefit in patients with a large change in EPCs in trial versus control patients $(P=0.012)$. There was no difference in OS in patients irrespective of the level of change of EPCs. In $\mathrm{CD} 45^{-}, \mathrm{CD} 34^{+}, \mathrm{CD} 31^{+}$and $\mathrm{CD} 133^{+}$EPCs there was a significant PFS benefit in trial patients with a small change in EPCs versus controls $(P=0.0008)$. In addition, there was a significant PFS benefit in trial patients with a large change in EPCs in trial versus control patients $(P=0.012)$. There was no difference in OS in patients irrespective of the degree of change in EPCs levels in trial versus control patients.

\section{Discussion}

This study aimed to assess the effect of administering intravenous $\omega$-3FAs in combination with gemcitabine chemotherapy on EPCs in patients with APC compared to gemcitabine monotherapy alone. Previous published data have demonstrated that intravenous administration of $\omega$-3FAs is well tolerated(23), results in rapid uptake into cell membranes and improves patient's quality of life(24-28) in advanced cancers. This study has some limitations. Firstly the trial and control groups are unmatched, with eighteen in the trial cohort and nine in the control cohort. Recruitment was limited to nine control patients as a result of the standard chemotherapy regime being changed following the introduction of nab-paclitaxel as a chemotherapeutic agent administered in addition to gemcitabine(29). This study compared treatment in two cohorts with patients recruited in succession as they presented and randomisation of patients and treatment would have reduced selection bias.

In this study we investigated the addition of Lipidem to standard gemcitabine chemotherapy. Lipidem contains $20 \mathrm{~g} \omega-3 F A s$ and 8.6-17.2 $\mathrm{g}$ of EPA and DHA in $1000 \mathrm{~mL}$. Ideally a more refined investigational product that contained a purer form of $\omega$-3FAs in a lower total volume would have been chosen. Lipidem was administered following the gemcitabine treatment as per standard protocol on days 1, 8 and 15, which was followed by a rest week. This was as a result of the Ethics Committee review that believed it was unacceptable to inconvenience patients by deviating from their standard treatment protocols with additional visits to the oncology department. Patients would ideally receive intravenous $\omega$-3FAs every week in order to maintain levels but 
altering the treatment course or administering high dose oral supplementation that would support intravenous administration is an alternative approach.

This study is the first to analyse EPCs at multiple treatment points in patients receiving intravenous $\omega-3 F A s$. The majority of other published studies only analyse baseline mediator levels and at one, two or three treatment points. There is general variability in EPC levels seen at each treatment point and multiple time point analysis is required to provide an accurate assessment of levels over a treatment period. This study provides an important and robust analysis of EPC changes which occur over a whole treatment period.

\section{EPCs}

In 1997 Asahara and colleagues isolated CD34+ hematopoietic cells in human peripheral blood $(20,30)$ which stimulated further investigation of endothelial progenitor cells. However, defining the exact phenotypic identification proved challenging (Table 2). EPCs are a subtype of stem cells with a high proliferative potential that are capable of differentiating into mature endothelial cells and contributing to neovascularization $(6,31)$. EPCs have the ability to migrate, colonise, proliferate and ultimately, differentiate into endothelial lineage cells(32). These progenitor cells are in a state of transformation and can be considered part of a development continuum. EPC recruitment and mobilisation have been shown to correlate with increased levels of angiogenic growth factors including vascular endothelial growth factor (VEGF)(33). VEGF is responsible for the proliferation, differentiation and chemotaxis of $\operatorname{EPCs}(32,34)$ and is released from tumour cells, macrophages and platelets(35). Other mediators and growth factors stimulating EPC recruitment include fibroblast growth factor (FGF), angiopoietin-1, stromal derived factor- 1 and placental growth factor(36-38).

The cancer stem cell hypothesis proposes a hierarchical organisation of tumours, in which a subpopulation of stem cell-like cells sustains tumour growth, metastasis and resistance to therapy(39). With recognition of the importance of these cells research into their specific elimination and manipulation becomes clinically relevant. There are myriad stem and progenitor cells involved in the tumorigenesis of pancreatic cancer including cancer stem cells, haematopoietic stem cells, very small embryonic/epiblast-like stem cells and endothelial stem/progenitor cells(40). The possible mechanism for the increase in EPCs in cancer may include the generalised activation of the endothelium, localised endothelial damage or an elevation in stimulating growth factors and mediators mobilising precursor cells(8). In addition, pancreatic cancer is notoriously hypoxic with an inflammatory stromal cuff that results in tumour release of mediators that result in EPC recruitment. However the mobilisation, recruitment and incorporation of EPCs into tumours is a complex and multi factor process that involves the participation of numerous mediators and cells in the tumour microenvironment(9) and the complete mechanisms are yet to be fully understood.

EPCs have been shown to be elevated in a number of different cancers (Table 2), and there is a recognised increase in EPC number in the peripheral blood of patients with increased tumour burden(41). Vizio et al(8) demonstrated that levels of EPCs were between 10 and 26 times higher in APC patients compared to healthy controls(8). They further demonstrated that increased EPC levels were significantly correlated with an increased TNM stage, a deteriorating prognosis and a poorer overall survival(8). In addition Ko et al(42) also demonstrated that baseline EPC concentration was inversely associated with overall survival in patients treated with bevacizumab plus erlotinib for gemcitabine refractory APC. There is a paucity of studies into the effect of chemotherapy regimes on EPCs in APC although there have been studies in other cancers. In immunodeficient mice bearing human lymphoma cells, Bertolini et al(43) demonstrated that frequent low dose administration of cyclophosphamide suppressed EPC numbers and viability with concurrent inhibition of tumour growth possibly resulting from the antivasculogenetic effect consequent upon reduced EPC mobilisation. A phase two study administering celocoxib and low dose cyclophosphamide in patients with non-Hodgkin's lymphoma demonstrated that EPC numbers dropped and remained low in responders(44). Additional studies in lymphoma administering endostatin, a naturally occurring anti-angiogenic agent derived from type XVIII collagen, compared to chemotherapy resulted in greater inhibition of EPCs, bone marrow neovascularisation and increased tumour suppression $(45,46)$. Several studies failed to demonstrate a significant rise in EPCs in human cancer, including lymphoma, breast cancer(47) and gastric cancer(48), despite elevation of VEGF levels. It is suggested that VEGF and other mediator levels in these cancers are not elevated sufficiently to stimulate EPC production and recruitment. Within cancer,

Page $9 / 20$ 
EPCs are incorporated in to the neo-endothelium and contribute to tumour vessel formation(49) and tumour growth(50). EPCs have been shown to play an important role in the growth of tumours at both early and late stages(51). Their exact role as either markers of altered vascular integrity or direct contributors to the neoplastic process is not clear(32), and it is also not known whether their increase is the result of systemic endothelial activation in response to the cancer, a result of endothelial shedding, a response to cytotoxic chemotherapy or as a result of tumour induced mediators and growth factors. Gemcitabine treatment has been shown to affect VEGF-A and circulating endothelial cells but not EPCs(8). It may be that EPCs play an important role in tumour resistance, neo angiogenesis and facilitate metastasis due to both instructive (release of pro angiogenic cytokines) and structural (vessel formation, incorporation and stabilisation) functions(8). Pancreatic cancer is often diagnosed at an advanced stage and as discussed is highly resistant to chemotherapy treatment. As a therapeutic tool EPCs could potentially be used as a marker of anti-angiogenic therapy, tumour burden and growth and angiogenesis. In addition, EPCs may be a suitable marker to predict response to therapy, metastasis or recurrence. This potential makes EPC research promising in respect of monitoring the success of treatment and therapeutic options, particularly in APC.

All three EPC phenotypes were significantly increased in the trial patients but not control patients. There was no significant change in EPC levels seen in patients treated with gemcitabine monotherapy. In addition, EPCs $\left(\mathrm{CD} 45^{-}, \mathrm{CD} 31^{+}, \mathrm{CD} 34^{+}\right.$and $\mathrm{CD} 45^{-}, \mathrm{CD} 34^{+}, \mathrm{CD} 31^{+}, \mathrm{CD} 133^{+}$phenotypes) were significantly increased compared with controls on comparison regression analysis. There was no significant increase in trial $\mathrm{CD} 45^{-}, \mathrm{CD} 31^{+}$and $\mathrm{CD} 133^{+}$EPCs compared to controls. These results demonstrate that EPCs are significantly increased in APC patients treated with intravenous $\omega$-3FAs. Interestingly an increase in EPCs had been previously demonstrated following $\omega$-3FAs administration in healthy volunteers $(52,53)$.

Theoretically if $\omega$-3FA administration reduces the numerous pro-angiogenic mediators there would be a concomitant reduction in EPCs over the $\omega$-3FA treatment period. However, $\omega$-3FA administration appears to increase EPCs over the period of the treatment although the detail of the underlying mechanisms presently remains undetermined. It is possible that the reduction of pro-inflammatory mediators that result during $\omega$-3FA treatment allows the expansion and recruitment of EPCs by alternative PAC mediators. Although reduction of the hypoxic stroma and inflammatory cuff seen in PAC should theoretically limit EPC expansion, there are clearly alternative mechanisms behind the EPC expansion seen with $\omega$-3FA treatment and this requires further investigation.

An increase in EPCs may also confer a survival benefit and this was seen with an increase in EPCs in the trial patients with a large change in the level of EPCs compared to control patients. In EPCs with a CD45 $5^{-}, \mathrm{CD} 31^{+}, \mathrm{CD} 133^{+}$and $\mathrm{CD} 45^{-}, \mathrm{CD} 31^{+}$and $\mathrm{CD} 34^{+}$phenotype there was a significant PFS and OS seen in trial patients with a large change of EPC levels compared with control patients. Additional analysis has observed a significant reduction in Platelet-derived growth factor (PDGF) and fibroblast growth factor (FGF) with omega 3 treatment over time(26). PDGF responders demonstrated a tendency towards improved OS and FGF responders a significantly improved PFS. The interaction between EPCs and growth factors in APC needs further investigation to determine if there is a therapeutic potential.

\section{Conclusion}

Administration of $\omega$-3FAs with gemcitabine chemotherapy in APC results in a significant increase in the number of EPCs and there appears to be a survival benefit in patients with an increase in EPC numbers. This may be the result of a reduction in proinflammatory mediators however additional studies are required to ascertain the underlying mechanisms and pathways and the related clinical benefits.

\section{Abbreviations}

AA - Arachadonic acid

ALA - Alpha linoleic acid

APC - Advanced pancreatic cancer

Page $10 / 20$ 
DHA - Docosahexaenoic acid

EDTA - Ethylenediaminetetraacetic acid

EPA - Eicosapentaenoic acid

EPC - Endothelial progenitor cells

FACS - Fluorescence-activated cell sorting

FGF - Fibroblast growth factor

FSC - Forward scatter

PAC - Pancreatic adenocarcinoma

PBMC - Peripheral blood mononuclear cell

MCAM - Melanoma cell adhesion molecule

MHRA - Medicines and Healthcare Products Regulatory Agency

NSCLC - Non-small cell lung cancer

OS - Overall survival

$\omega$-3FAs - Omega 3 fatty acids

$\omega-6 F A s$ - Omega 6 fatty acids

PECAM-1 - Platelet and endothelial cell adhesion molecule 1

PDGF - Platelet derived growth factor

PFS - Progression free survival

RECIST - Response evaluation criteria in solid tumours

SSC - Side scatter

TNM - Tumour node metastasis

VEGF - Vascular endothelial growth factor

VEGFR-2 - Vascular endothelial growth factor receptor 2

\section{Declarations}

\section{Ethics approval and consent to participate}

Written consent was obtained from all study participants as per trial protocol and the local Ethics Committee and the Medicines and Healthcare Products Regulatory Agency (MHRA) approved both studies. All patients were assessed against trial protocol inclusion/exclusion criteria. The trial was registered with clinicaltrials.gov (Number:NCT01019382).

\section{Consent for publication}




\section{Availability of data and material-}

The datasets used and/or analysed during the current study are available from the corresponding author on reasonable request.

\section{Competing interests}

The authors declare that they have no competing interests.

\section{Funding}

Institutional funding was utilized and the investigative product provided by B.Braun.

\section{Authors' contributions}

JI- Patient recruitment, sample analysis, data analysis, manuscript writing.

AA- Trial design, patient recruitment, sample analysis, data analysis, manuscript writing.

WC- Patient recruitment, sample analysis, data analysis, manuscript writing.

FR- Patient recruitment, sample analysis, manuscript writing.

JC- Patient recruitment, sample analysis.

CP- Trial design, patient recruitment.

LH- sample analysis, data analysis, manuscript writing.

JF - sample analysis, data analysis, manuscript writing.

JT- sample analysis, data analysis.

MSM - Trial design, patient recruitment, manuscript writing.

WS - Trial design, patient recruitment, manuscript writing.

ARD - Trial design, patient recruitment, manuscript writing.

\section{Acknowledgements}

B.Braun supplied the investigated product Lipidem

\section{Financial disclosure and conflicts of interest statement}

None Declared

\section{Conflicts of interest and funding sources}

Page $12 / 20$ 
The investigational product was provided by BBraun.

\section{References}

1. Statistics 0 for N. Mortality Statistics: Cause: England and Wales. 2007.

2. Jemal A, Bray F, Center MM, Ferlay J, Ward E, Forman D. Global cancer statistics. CA Cancer J Clin [Internet]. 2011 Mar [cited 2016 Sep 28];61(2):69-90. Available from: http://doi.wiley.com/10.3322/caac.20107

3. Gillen S, Schuster T, Meyer zum Büschenfelde C, Friess H, Kleeff J. Preoperative/Neoadjuvant Therapy in Pancreatic Cancer: A Systematic Review and Meta-analysis of Response and Resection Percentages. Seiler C, editor. PLoS Med [Internet]. 2010 Apr 20 [cited 2017 Mar 29];7(4):e1000267. Available from: http://dx.plos.org/10.1371/journal.pmed.1000267

4. DiMagno EP, Reber HA, Tempero MA. AGA technical review on the epidemiology, diagnosis, and treatment of pancreatic ductal adenocarcinoma. American Gastroenterological Association. Gastroenterology [Internet]. 1999 Dec [cited 2017 Mar 28];117(6):1464-84. Available from: http://www.ncbi.nlm.nih.gov/pubmed/10579989

5. Li D, Xie K, Wolff R, Abbruzzese JL. Pancreatic cancer. Lancet (London, England) [Internet]. 2004 Mar 27 [cited 2017 Mar 28];363(9414):1049-58. Available from: http://linkinghub.elsevier.com/retrieve/pii/S0140673604158418

6. de la Puente P, Muz B, Azab F, Azab AK. Cell trafficking of endothelial progenitor cells in tumor progression. Clin Cancer Res [Internet]. 2013 Jul 1 [cited 2017 May 3];19(13):3360-8. Available from: http://clincancerres.aacrjournals.org/cgi/doi/10.1158/1078-0432.CCR-13-0462

7. Greenblatt M, Shubi P. Tumor angiogenesis: transfilter diffusion studies in the hamster by the transparent chamber technique. J Natl Cancer Inst [Internet]. 1968 Jul [cited 2017 May 3];41(1):111-24. Available from:

http://www.ncbi.nlm.nih.gov/pubmed/5662020

8. Vizio B, Novarino A, Giacobino A, Cristiano C, Prati A, Brondino G, et al. Pilot study to relate clinical outcome in pancreatic carcinoma and angiogenic plasma factors/circulating mature/progenitor endothelial cells: Preliminary results. Cancer Sci [Internet]. 2010 Nov [cited 2014 Jul 8];101(11):2448-54. Available from: http://www.ncbi.nlm.nih.gov/pubmed/20950371

9. Ding Y, Kumar S, Yu D. The role of endothelial progenitor cells in tumour vasculogenesis. Pathobiology [Internet]. 2008 [cited 2017 May 10];75(5):265-73. Available from: http://www.karger.com/doi/10.1159/000151706

10. Lin Y, Weisdorf DJ, Solovey A, Hebbel RP. Origins of circulating endothelial cells and endothelial outgrowth from blood. J Clin Invest [Internet]. 2000 Jan 1 [cited 2017 May 10];105(1):71-7. Available from: http://www.jci.org/articles/view/8071

11. Burger PE, Coetzee S, McKeehan WL, Kan M, Cook P, Fan Y, et al. Fibroblast growth factor receptor-1 is expressed by endothelial progenitor cells. Blood [Internet]. 2002 Nov 15 [cited 2017 May 11];100(10):3527-35. Available from: http://www.bloodjournal.org/cgi/doi/10.1182/blood.V100.10.3527

12. Rafii S, Lyden D, Benezra R, Hattori K, Heissig B. Vascular and haematopoietic stem cells: novel targets for antiangiogenesis therapy? Nat Rev Cancer [Internet]. 2002 Nov [cited 2017 May 11];2(11):826-35. Available from: http://www.ncbi.nlm.nih.gov/pubmed/12415253

13. Zhang W, Long Y, Zhang J, Wang C. Modulatory effects of EPA and DHA on proliferation and apoptosis of pancreatic cancer cells. J Huazhong Univ Sci Technol Sci = Hua zhong ke ji da xue xue baoYi xue Ying wen ban = Huazhong keji daxue xuebaoYixue Yingdewen ban [Internet]. 2007 Oct [cited 2014 Jul 8];27(5):547-50. Available from: http://www.ncbi.nlm.nih.gov/pubmed/18060632

14. Hering J, Garrean S, Dekoj TR, Razzak A, Saied A, Trevino J, et al. Inhibition of proliferation by omega-3 fatty acids in chemoresistant pancreatic cancer cells. Ann Surg Oncol. 2007 Dec;14(12):3620-8.

15. Murphy MG. Dietary fatty acids and membrane protein function. J Nutr Biochem [Internet]. 1990 Feb [cited 2017 May 12];1(2):68-79. Available from: http://www.ncbi.nlm.nih.gov/pubmed/15539188

16. Stubbs CD, Smith AD. The modification of mammalian membrane polyunsaturated fatty acid composition in relation to membrane fluidity and function. Biochim Biophys Acta [Internet]. 1984 Jan 27 [cited 2017 May 12];779(1):89-137. Available from: http://www.ncbi.nlm.nih.gov/pubmed/6229284 
17. Yaqoob P. The Nutritional Significance of Lipid Rafts. Annu Rev Nutr [Internet]. 2009 Aug [cited 2017 May 12];29(1):257-82. Available from: http://www.ncbi.nlm.nih.gov/pubmed/19400697

18. Miles EA, Calder PC. Modulation of immune function by dietary fatty acids. Proc Nutr Soc [Internet]. 1998 May [cited 2017 May 12];57(2):277-92. Available from: http://www.ncbi.nlm.nih.gov/pubmed/9656331

19. Khan SS, Solomon MA, McCoy JP. Detection of circulating endothelial cells and endothelial progenitor cells by flow cytometry. Cytom Part B Clin Cytom [Internet]. 2005 Mar [cited 2017 May 3];64B(1):1-8. Available from: http://www.ncbi.nlm.nih.gov/pubmed/15668988

20. Fadini GP, Losordo D, Dimmeler S. Critical reevaluation of endothelial progenitor cell phenotypes for therapeutic and diagnostic use. Circ Res [Internet]. 2012 Feb 17 [cited 2014 Jun 19];110(4):624-37. Available from:

http://www.pubmedcentral.nih.gov/articlerender.fcgi?artid=3382070\&tool=pmcentrez\&rendertype=abstract

21. Gehling UM, Ergün S, Schumacher U, Wagener C, Pantel K, Otte M, et al. In vitro differentiation of endothelial cells from AC133-positive progenitor cells. Blood. 2000;95(10):3106-12.

22. Danova M, Comolli G, Manzoni M, Torchio M, Mazzini G. Flow cytometric analysis of circulating endothelial cells and endothelial progenitors for clinical purposes in oncology: A critical evaluation (Review). Mol Clin Oncol [Internet]. 2016 Mar 18 [cited 2017 May 10];4(6):909-17. Available from: http://www.ncbi.nlm.nih.gov/pubmed/27284422

23. Simoens CM, Deckelbaum RJ, Massaut JJ, Carpentier YA. Inclusion of $10 \%$ fish oil in mixed medium-chain triacylglycerollong-chain triacylglycerol emulsions increases plasma triacylglycerol clearance and induces rapid eicosapentaenoic acid (20:5n-3) incorporation into blood cell phospholipids. Am J Clin Nutr [Internet]. 2008 Aug [cited 2017 Jun 3];88(2):282-8. Available from: http://www.ncbi.nlm.nih.gov/pubmed/18689362

24. Arshad A, Isherwood J, Mann C, Cooke J, Pollard C, Runau F, et al. Intravenous w-3 Fatty Acids Plus Gemcitabine. J Parenter Enter Nutr [Internet]. 2017 Mar [cited 2017 May 13];41(3):398-403. Available from:

http://www.ncbi.nlm.nih.gov/pubmed/26220200

25. Eltweri AM, Thomas AL, Fisk HL, Arshad A, Calder PC, Dennison AR, et al. Plasma and erythrocyte uptake of omega-3 fatty acids from an intravenous fish oil based lipid emulsion in patients with advanced oesophagogastric cancer. Clin Nutr [Internet]. 2017 Jun [cited 2017 May 16];36(3):768-74. Available from: http://www.ncbi.nlm.nih.gov/pubmed/27342748

26. Arshad A, Chung WY, Steward W, Metcalfe MS, Dennison AR. Reduction in circulating pro-angiogenic and pro-inflammatory factors is related to improved outcomes in patients with advanced pancreatic cancer treated with gemcitabine and intravenous omega-3 fish oil. HPB (Oxford) [Internet]. 2013 Jun [cited 2016 Sep 28];15(6):428-32. Available from: http://www.ncbi.nlm.nih.gov/pubmed/23458624

27. Arshad A, Chung WY, Isherwood J, Mann CD, Al-Leswas D, Steward WP, et al. Cellular and plasma uptake of parenteral omega-3 rich lipid emulsion fatty acids in patients with advanced pancreatic cancer. Clin Nutr [Internet]. 2014 Oct [cited 2017 May 13];33(5):895-9. Available from: http://www.ncbi.nlm.nih.gov/pubmed/24140233

28. Arshad a, Al-Leswas D, Stephenson J, Metcalfe M, Dennison A. Potential applications of fish oils rich in n-3 fatty acids in the palliative treatment of advanced pancreatic cancer. Br J Nutr [Internet]. 2011 Sep [cited 2014 Jul 8];106(6):795-800. Available from: http://www.ncbi.nlm.nih.gov/pubmed/21745426

29. Von Hoff DD, Ervin T, Arena FP, Chiorean EG, Infante J, Moore M, et al. Increased survival in pancreatic cancer with nabpaclitaxel plus gemcitabine. N Engl J Med. 2013;369(18).

30. Asahara T, Murohara T, Sullivan A, Silver M, van der Zee R, Li T, et al. Isolation of putative progenitor endothelial cells for angiogenesis. Science [Internet]. 1997 Feb 14 [cited 2016 Oct 8];275(5302):964-7. Available from:

http://www.ncbi.nlm.nih.gov/pubmed/9020076

31. Peichev M, Naiyer a J, Pereira D, Zhu Z, Lane WJ, Williams M, et al. Expression of VEGFR-2 and AC133 by circulating human CD34(+) cells identifies a population of functional endothelial precursors. Blood. 2000;95(3):952-8.

32. Goon PKY, Lip GYH, Boos CJ, Stonelake PS, Blann AD. Circulating Endothelial Cells, Endothelial Progenitor Cells, and Endothelial Microparticles in Cancer. Neoplasia [Internet]. 2006 Feb [cited 2016 Sep 28];8(2):79-88. Available from: http://linkinghub.elsevier.com/retrieve/pii/S1476558606801156 
33. Shintani S, Murohara T, Ikeda H, Ueno T, Honma T, Katoh A, et al. Mobilization of endothelial progenitor cells in patients with acute myocardial infarction. Circulation [Internet]. 2001 Jun 12 [cited 2017 May 3];103(23):2776-9. Available from: http://www.ncbi.nlm.nih.gov/pubmed/11401930

34. Carmeliet P, Ferreira V, Breier G, Pollefeyt S, Kieckens L, Gertsenstein M, et al. Abnormal blood vessel development and lethality in embryos lacking a single VEGF allele. Nature [Internet]. 1996 Apr 4 [cited 2017 May 3];380(6573):435-9. Available from: http://www.nature.com/doifinder/10.1038/380435a0

35. George ML, Eccles SA, Tutton MG, Abulafi AM, Swift RI. Correlation of plasma and serum vascular endothelial growth factor levels with platelet count in colorectal cancer: clinical evidence of platelet scavenging? Clin Cancer Res [Internet]. 2000 Aug [cited 2017 May 3];6(8):3147-52. Available from: http://www.ncbi.nlm.nih.gov/pubmed/10955796

36. Hattori K, Dias S, Heissig B, Hackett NR, Lyden D, Tateno M, et al. Vascular endothelial growth factor and angiopoietin-1 stimulate postnatal hematopoiesis by recruitment of vasculogenic and hematopoietic stem cells. J Exp Med [Internet]. 2001 May 7 [cited 2017 May 3];193(9):1005-14. Available from: http://www.ncbi.nlm.nih.gov/pubmed/11342585

37. Asahara T, Masuda H, Takahashi T, Kalka C, Pastore C, Silver M, et al. Bone marrow origin of endothelial progenitor cells responsible for postnatal vasculogenesis in physiological and pathological neovascularization. Circ Res [Internet]. 1999 Aug 6 [cited 2017 May 3];85(3):221-8. Available from: http://www.ncbi.nlm.nih.gov/pubmed/10436164

38. Yamaguchi J, Kusano KF, Masuo O, Kawamoto A, Silver M, Murasawa S, et al. Stromal cell-derived factor-1 effects on ex vivo expanded endothelial progenitor cell recruitment for ischemic neovascularization. Circulation [Internet]. 2003 Mar 11 [cited 2017 May 3];107(9):1322-8. Available from: http://www.ncbi.nlm.nih.gov/pubmed/12628955

39. Lonardo E, Hermann PC, Heeschen C. Pancreatic cancer stem cells e update and future perspectives. Mol Oncol [Internet]. 2010;4(5):431-42. Available from: http://dx.doi.org/10.1016/j.molonc.2010.06.002

40. Starzynska T, Dabkowski K, Blogowski W, Zuba-Surma E, Budkowska M, Salata D, et al. An intensified systemic trafficking of bone marrow-derived stem/progenitor cells in patients with pancreatic cancer. J Cell Mol Med [Internet]. 2013 Jun [cited 2014 Jul 8];17(6):792-9. Available from: http://www.ncbi.nlm.nih.gov/entrez/query.fcgi?

cmd=Retrieve\&db=PubMed\&dopt=Citation\&list_uids=23672538

41. Bertolini F, Shaked Y, Mancuso P, Kerbel RRS. The multifaceted circulating endothelial cell in cancer: towards marker and target identification. Nat Rev Cancer [Internet]. 2006 Nov [cited 2014 May 24];6(November):835-45. Available from: http://www.ncbi.nlm.nih.gov/pubmed/17036040\%5Cnhttp://www.nature.com/nrc/journal/vaop/ncurrent/full/nrc1971.html

42. Ko AH, Venook AP, Bergsland EK, Kelley RK, Korn WM, Dito E, et al. A phase II study of bevacizumab plus erlotinib for gemcitabine-refractory metastatic pancreatic cancer. Cancer Chemother Pharmacol [Internet]. 2010 Nov 4 [cited 2016 Sep 28];66(6):1051-7. Available from: http://link.springer.com/10.1007/s00280-010-1257-5

43. Bertolini F, Paul S, Mancuso P, Monestiroli S, Gobbi A, Shaked Y, et al. Maximum tolerable dose and low-dose metronomic chemotherapy have opposite effects on the mobilization and viability of circulating endothelial progenitor cells. Cancer Res [Internet]. 2003 Aug 1 [cited 2017 May 11];63(15):4342-6. Available from: http://www.ncbi.nlm.nih.gov/pubmed/12907602

44. Buckstein R, Kerbel RS, Shaked Y, Nayar R, Foden C, Turner R, et al. High-Dose Celecoxib and Metronomic \&quot;Lowdose\&quot; Cyclophosphamide Is an Effective and Safe Therapy in Patients with Relapsed and Refractory Aggressive Histology Non-Hodgkin's Lymphoma. Clin Cancer Res [Internet]. 2006 Sep 1 [cited 2017 May 12];12(17):5190-8. Available from: http://www.ncbi.nlm.nih.gov/pubmed/16951238

45. Schuch G, Heymach J V, Nomi M, Machluf M, Force J, Atala A, et al. Endostatin inhibits the vascular endothelial growth factor-induced mobilization of endothelial progenitor cells. Cancer Res [Internet]. 2003 Dec 1 [cited 2017 May 11];63(23):8345-50. Available from: http://www.ncbi.nlm.nih.gov/pubmed/14678995

46. Capillo M, Mancuso P, Gobbi A, Monestiroli S, Pruneri G, Dell'Agnola C, et al. Continuous infusion of endostatin inhibits differentiation, mobilization, and clonogenic potential of endothelial cell progenitors. Clin Cancer Res [Internet]. 2003 Jan [cited 2017 May 11];9(1):377-82. Available from: http://www.ncbi.nlm.nih.gov/pubmed/12538491

47. Mancuso P, Burlini A, Pruneri G, Goldhirsch A, Martinelli G, Bertolini F. Resting and activated endothelial cells are increased in the peripheral blood of cancer patients. Blood [Internet]. 2001 Jun 1 [cited 2017 May 11];97(11):3658-61. Available from: http://www.ncbi.nlm.nih.gov/pubmed/11369666

Page 15/20 
48. Kim HK, Song KS, Kim HO, Chung J-H, Lee KR, Lee Y-J, et al. Circulating numbers of endothelial progenitor cells in patients with gastric and breast cancer. Cancer Lett [Internet]. 2003 Jul 30 [cited 2017 May 11];198(1):83-8. Available from: http://www.ncbi.nlm.nih.gov/pubmed/12893434

49. Lyden D, Hattori K, Dias S, Costa C, Blaikie P, Butros L, et al. Impaired recruitment of bone-marrow-derived endothelial and hematopoietic precursor cells blocks tumor angiogenesis and growth. Nat Med [Internet]. 2001 Nov 1 [cited 2017 May 3];7(11):1194-201. Available from: http://www.nature.com/doifinder/10.1038/nm1101-1194

50. Garmy-Susini B, Varner JA. Circulating endothelial progenitor cells. Br J Cancer [Internet]. 2005 Oct 17 [cited 2017 May 3];93(8):855-8. Available from: http://www.ncbi.nlm.nih.gov/pubmed/16189517

51. Stoll BR, Migliorini C, Kadambi A, Munn LL, Jain RK. A mathematical model of the contribution of endothelial progenitor cells to angiogenesis in tumors: implications for antiangiogenic therapy. Blood [Internet]. 2003 Oct 1 [cited 2017 May 3];102(7):2555-61. Available from: http://www.bloodjournal.org/cgi/doi/10.1182/blood-2003-02-0365

52. Spigoni V, Lombardi C, Cito M, Picconi A, Ridolfi V, Andreoli R, et al. N-3 PUFA increase bioavailability and function of endothelial progenitor cells. Food Funct [Internet]. 2014 May 15 [cited 2017 May 12];5(8):1881. Available from: http://xlink.rsc.org/?DOI=C3F060641D

53. Wu S-Y, Mayneris-Perxachs J, Lovegrove JA, Todd S, Yaqoob P. Fish-oil supplementation alters numbers of circulating endothelial progenitor cells and microparticles independently of eNOS genotype. Am J Clin Nutr [Internet]. 2014 Nov 1 [cited 2017 May 12];100(5):1232-43. Available from: http://ajcn.nutrition.org/cgi/doi/10.3945/ajcn.114.088880

54. DeLisser HM, Christofidou-Solomidou M, Strieter RM, Burdick MD, Robinson CS, Wexler RS, et al. Involvement of endothelial PECAM-1/CD31 in angiogenesis. Am J Pathol [Internet]. 1997 Sep [cited 2016 Oct 8];151(3):671-7. Available from: http://www.ncbi.nlm.nih.gov/pubmed/9284815

55. Bühring HJ, Seiffert M, Bock TA, Scheding S, Thiel A, Scheffold A, et al. Expression of novel surface antigens on early hematopoietic cells. Ann N Y Acad Sci [Internet]. 1999 Apr 30 [cited 2016 Oct 8];872:25-38; discussion 38-9. Available from: http://www.ncbi.nlm.nih.gov/pubmed/10372108

56. Zimmerlin L, Donnenberg VS, Rubin JP, Donnenberg AD. Mesenchymal markers on human adipose stem/progenitor cells. Cytom Part A [Internet]. 2013 Jan [cited 2017 May 10];83A(1):134-40. Available from:

http://www.ncbi.nlm.nih.gov/pubmed/23184564

\section{Figures}




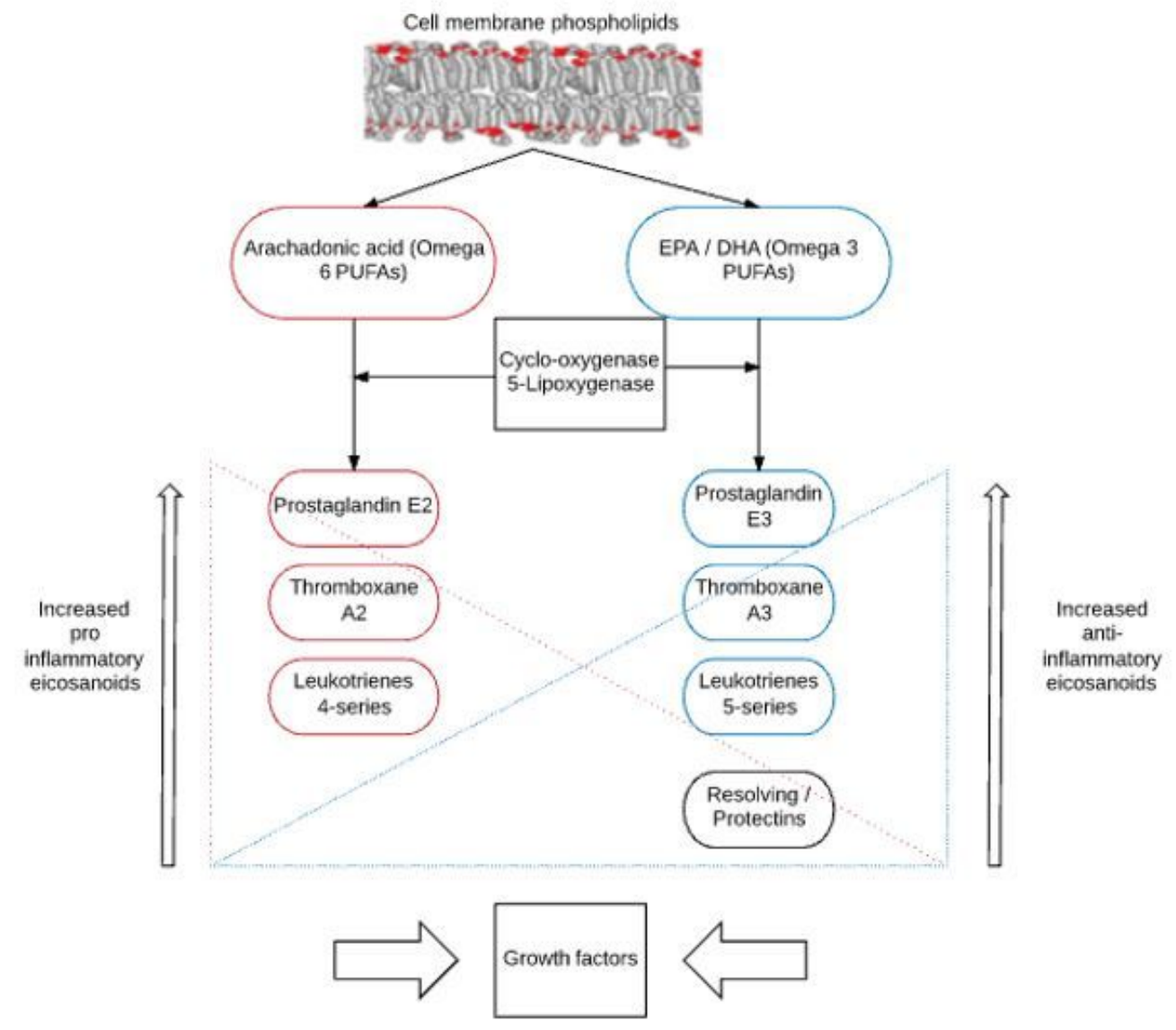

\section{Figure 1}

Eicosanoids derived from $\omega-3$ FAs (EPA and DHA) and $\omega$-6FAs (AA). They are metabolised by cyclooxygenase and lipoxygenase. The anti-inflammatory eicosanoids produced by $\omega$-3FAs include the 3 series prostaglandins and thromboxanes and the 5 series leukotrienes. The pro inflammatory eicosanoids produced by $\omega$-6FAs include the 2 series prostaglandins and thromboxanes and the 4 series leukotrienes. Increasing the amount of $\omega$-3FAs improves the $\omega-3$ FAs: $\omega-6 F A s$ ratio and reduces the amount of $\omega$-6FAs, particularly AA, present in the cell membrane and therefore the amount available for downstream pro inflammatory eicosanoid production. All these secondary mediators have either a general suppressive or enhancing effect on growth factors and cells in the inflammatory microenvironment. 

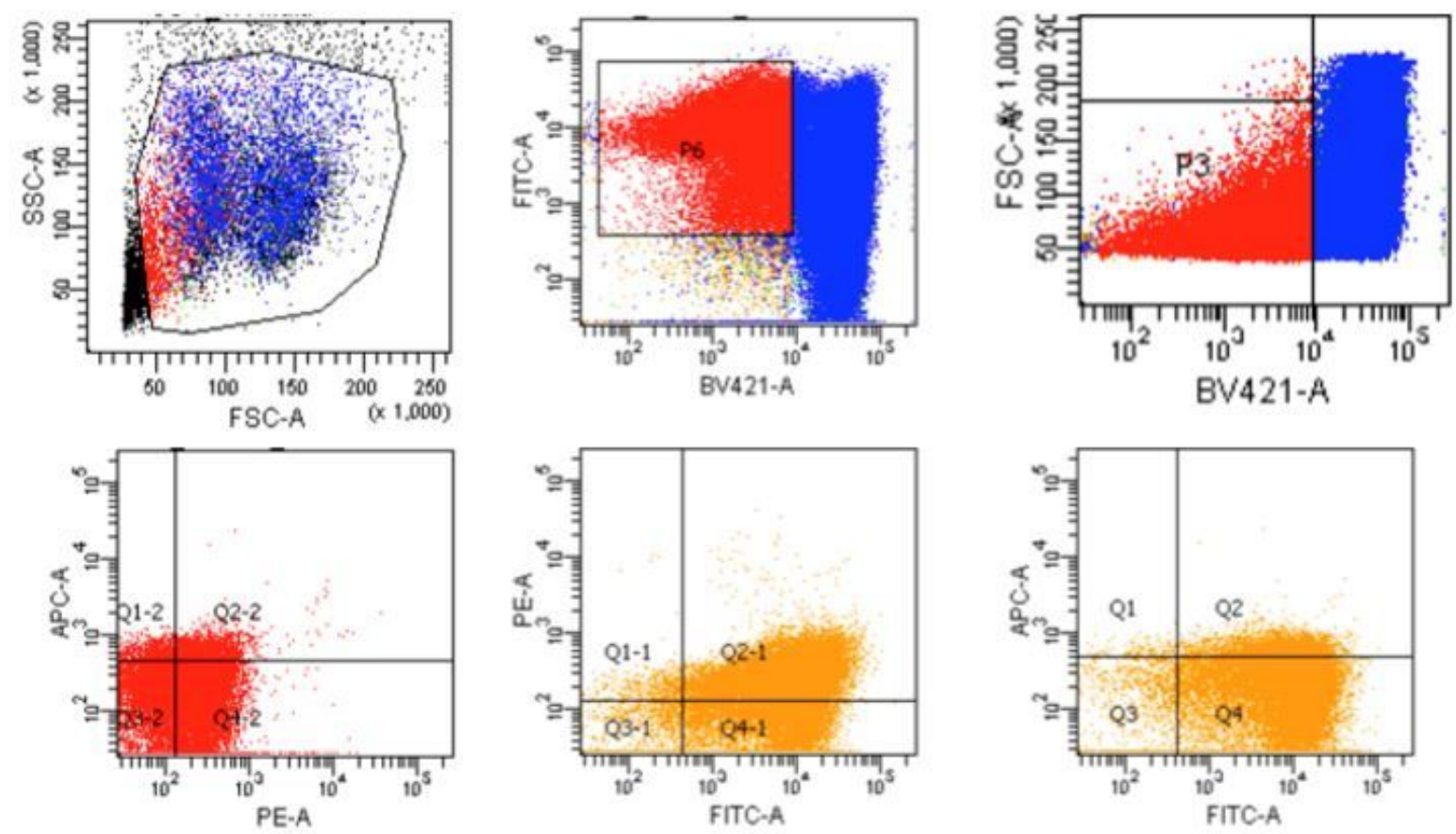

Figure 2

FACS schematic scatter plots of EPCs with a quadruple stain for CD45-, CD31+, CD133+ and CD34+ antibodies. The top left plot shows side scatter (SSC) versus forward scatter (FSC). A mean of 374,796 cells in the target population (P1) were analysed over the one hundred and thirty-four samples investigated. Three populations of EPCs were analysed. EPCs with a CD45-, CD31+, CD133+ and CD34+ phenotype are seen in Q2.2 (CD133+ (APC) and CD34+ (PE)), gated off P6 (CD31+ (FITC) \& CD45- (R/B220 pacific blue). EPCs with a CD45-, CD31+and CD34+ phenotype are seen in Q2.1 (CD34+ (PE) and CD31+ (FITC)), gated off P3 (CD45- (R/B220 pacific blue). EPCs with a CD45-, CD31+and CD133+ phenotype are seen in Q2 (CD31+ (FITC) and CD133+ (APC)), gated P3 (CD45- (R/B220 pacific blue). 


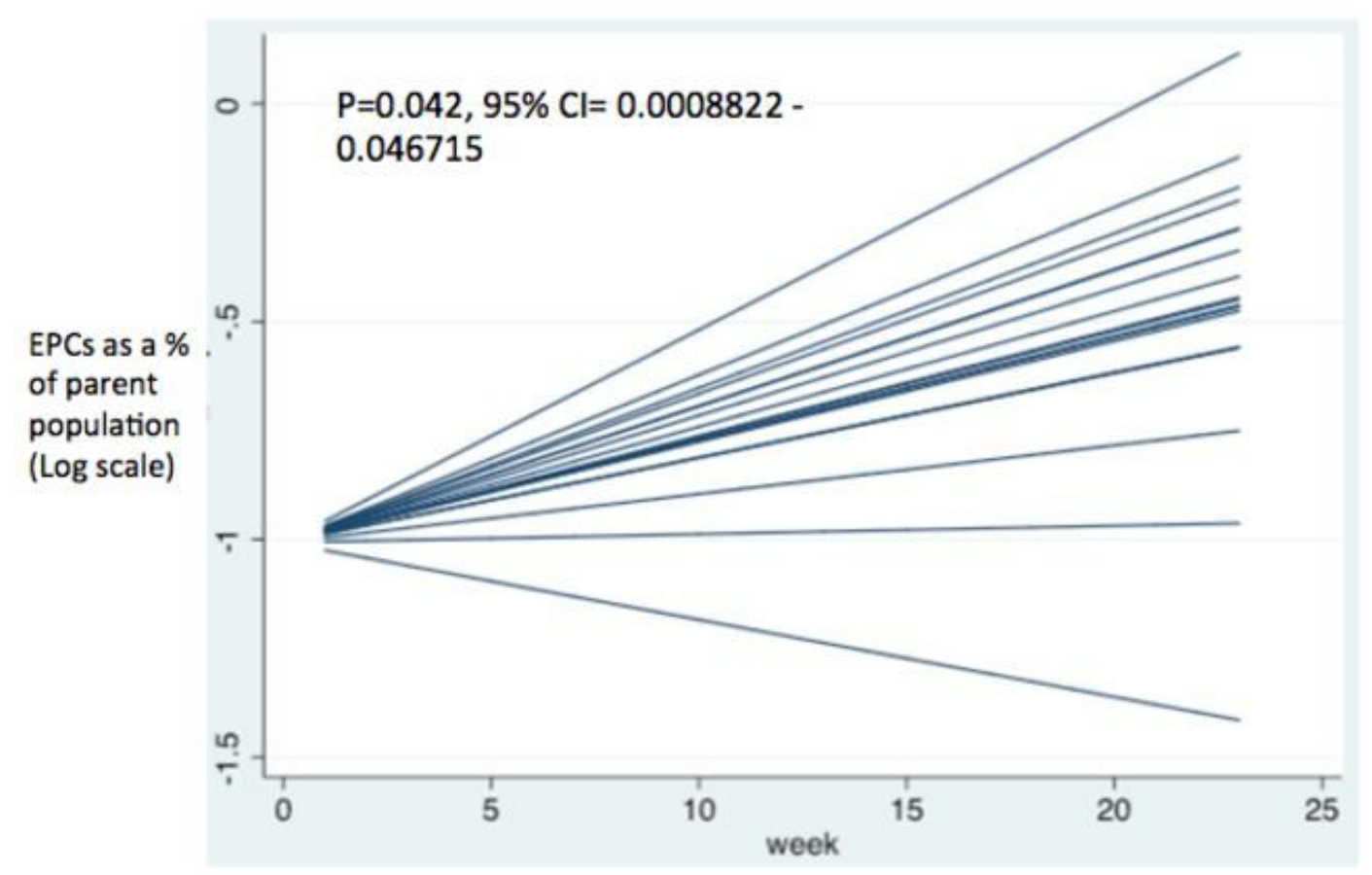

\section{Figure 3}

Output graph showing regression lines for individual patients plotted against time in weeks following mixed effects logistic regression analysis. EPCs levels are shown on the $y$ axis and are a calculated as a percentage of the parent population (log scale), time in weeks is shown on the $x$ axis. Each regression line represents a patient. One hundred and three time points in eighteen patients were analysed. There was a significant increase in EPCs over treatment $(\mathrm{P}=0.042,95 \% \mathrm{Cl}=0.0008-0.046)$.

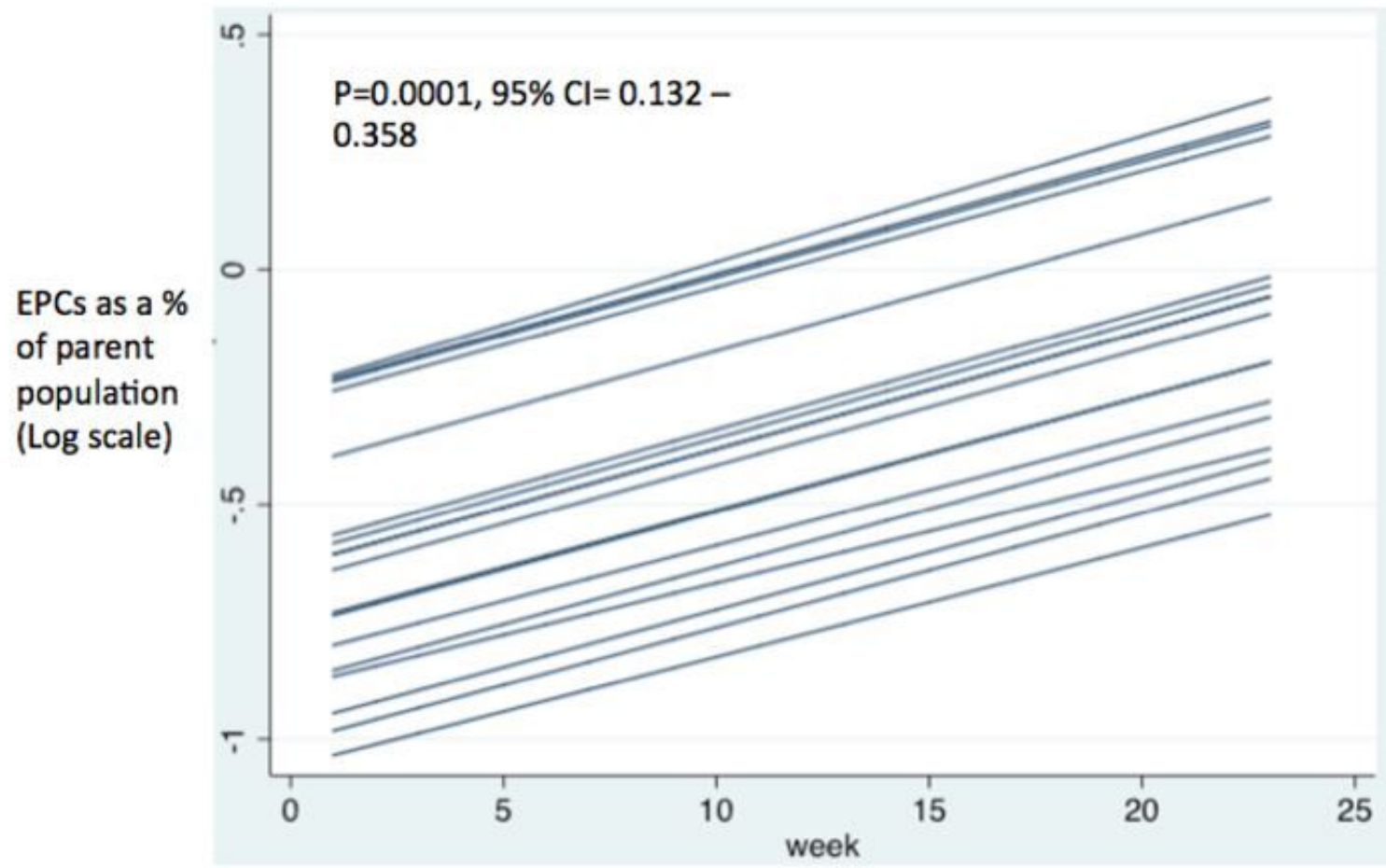




\section{Figure 4}

Output graph showing regression lines for individual patients plotted against time in weeks following mixed effects logistic regression analysis. EPCs levels are shown on the $y$ axis and are a calculated as a percentage of the parent population (log scale), time in weeks is shown on the $x$ axis. Each regression line represents a patient. One hundred and two time points in eighteen patients were analysed. There was a significant overall increasing trend in EPCs over time $(P=0.0001,95 \% \mathrm{Cl}=0.132$ 0.385).

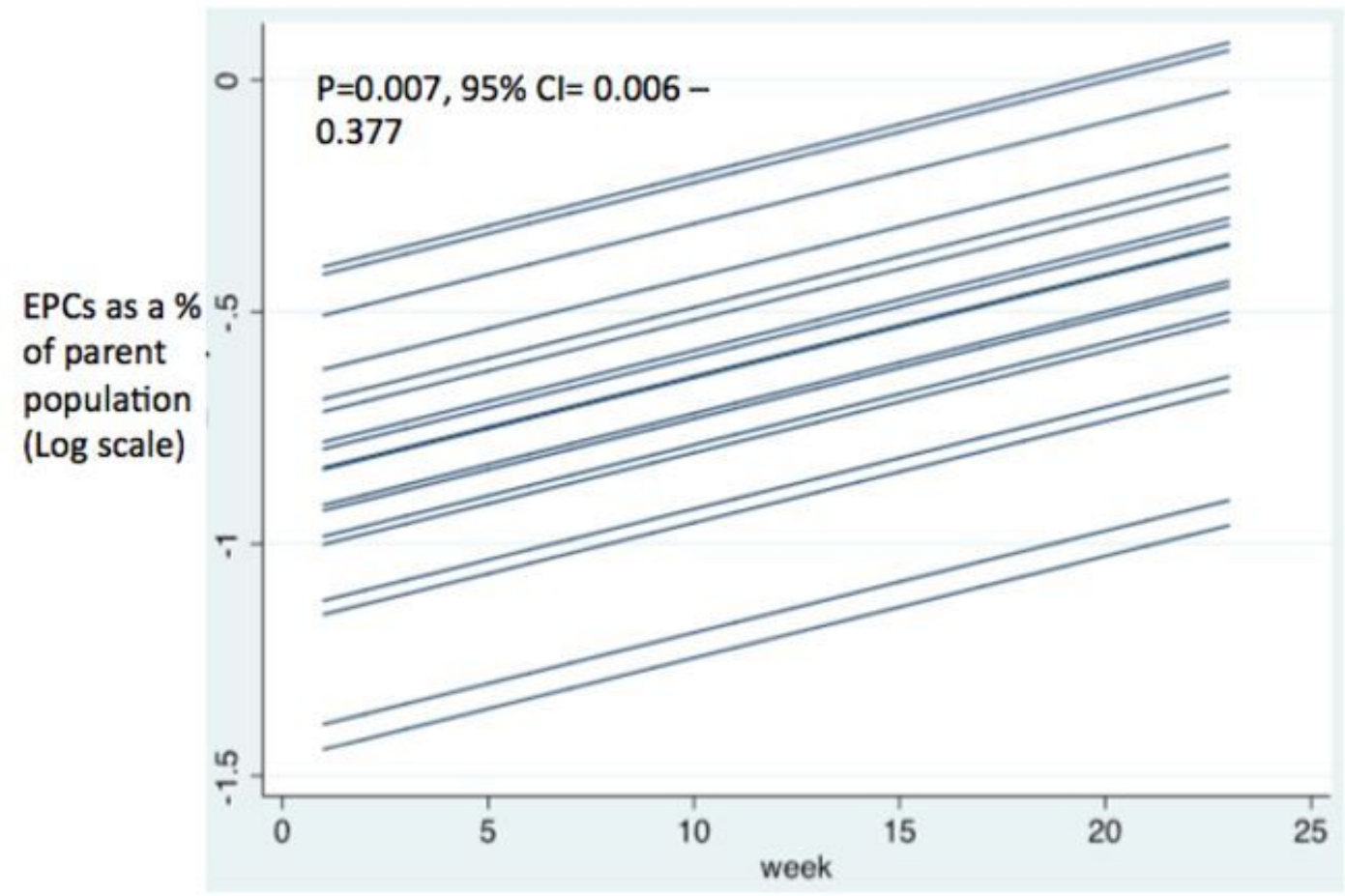

\section{Figure 5}

Output graph showing regression lines for individual patients plotted against time in weeks following mixed effects logistic regression analysis. EPCs levels are shown on the $y$ axis and are a calculated as a percentage of the parent population (log scale), time in weeks is shown on the $x$ axis. Each regression line represents a patient. Twenty-seven samples in nine patients were analysed. EPCs are calculated as a percentage of the parent population and plotted on a log scale. One hundred and three time points in eighteen patients were analysed. There is a significant increase in EPCs over time $(\mathrm{P}=0.007,95 \% \mathrm{Cl}=0.006$ 0.377). 